УДК 316.4.066

DOI: https://doi.org/10.33120/ssj.vi46(49).175

\author{
Коваль Геннадій Валерійович, \\ аспірант кафедри психології, \\ Запорізький національний університет, \\ м. Запоріжжя, Україна. \\ ORCID 0000-0002-3250-0128 \\ Gennadiy83zp@i.ua
}

\title{
ДО АНАЛІЗУ ПРОБЛЕМИ ДЕМАРКАЦІЇ СКЛАДОВИХ СОЦІАЛЬНО-ПСИХОЛОГІЧНОЇ ТАКСОНОМІї
}

\begin{abstract}
Статтю присвячено розгляду проблематики демаркації складових соціальнопсихологічної таксономії. Як метод дослідження застосовано теоретичний аналіз вітчизняного та пострадянського соціально-психологічного дискурсу. Показано, що проблема демаркації складових соціально-психологічної таксономії стосується насамперед розмивання упорядкованості на рівні співвідношення та обсягу таксона. Зауважено, що під кутом зору первинної специфікації соціально-психологічного таксона постульовано його принципову складеність з елементів. У зв'язку з цим за критерій первинної специфікації взято можливість обчислення елементів таксона і його результат, унаслідок чого вторинна специфікація таксона набуває залежності від якісної специфіки тих елементів, що становлять сукупність. Підкреслено, що якісна специфіка елементів сукупності виникає 3 диференціації понять елемент/одиниця. Зазначена закономірність підводить проблематику демаркації складових соціально-психологічної таксономії під дискурс ідеї цілого. Зауважено, що соціальнопсихологічна інтерпретація ідеї цілого в контексті проблематики демаркації складових соціально-психологічної таксономії зумовлює відтворення усталеної проблеми цілісності, а також порушує суто предметно-специфічне питання щодо специфіки постання об'єктів соціально-психологічної таксономії, де цілісність є формотворчим принципом. Показано можливість екстраполяції методичних настанов, вироблених для концепту “одиниця аналізу психічного", на концепт "одиниця аналізу соціально-психологічного". При цьому обгрунтовано підведення під зміст концепту "одиниця аналізу соціально-психологічного" терміна “особистість”. Обгрунтовано формулювання проблеми демаркації складових соціально-психологічної таксономії як питання про варіативність соціально-психологічних форм психічного. Як емпіричну інтерпретацію взаємозв'язку проблеми варіативності соціально-психологічних форм психічного 3 проблемними обширами іiі перспективної розробки зроблено припущення про специфіку соціально-психологічної зумовленості характеристик образу.
\end{abstract}

Ключові слова: соціально-психологічна одиниця; соціально-психологічна таксономія; колективна суб’єктність; форма психіки.

\section{TO THE ISSUE OF DEMARCATION OF SOCIO-PSYCHOLOGICAL TAXONOMY'S COMPONENTS}

\author{
Hennadiy V. Koval \\ Ph.D. student, Department of Psychology, \\ Zaporizhzhia National University, \\ Zaporizhzhya, Ukraine \\ ORCID 0000-0002-3250-0128 \\ Gennadiy83zp@i.ua
}

The article is dedicated to the issue of demarcation of components of socio-psychological taxonomy. Theoretical analysis of national and post-Soviet socio-psychological discourse is used as a research method. It is shown that the problem of demarcation of components of social- 
psychological taxonomy, first of all, refers to the blurring of orderliness at the level of the ratio and volume of the taxon. It is noted that from the point of view of the primary specification of the sociopsychological taxon it is postulated its fundamental composition of elements. In this regard, the criterion of the primary specification is the ability to calculate the elements of the taxon and its result, due to which the secondary specification of the taxon becomes dependent on the qualitative specificity of the elements that make up the summation. It is emphasized that the qualitative specificity of the elements of the population arises from the differentiation of the concepts of element/unit. This pattern brings the issue of demarcation of the components of socio-psychological taxonomy under the discourse of the idea of the whole. It is noted that the socio-psychological interpretation of the idea of the whole in the context of the demarcation of the components of sociopsychological taxonomy causes the reproduction of the established problem of integrity, and also raises a purely subject-specific question about the specifics of socio-psychological taxonomy, where the integrity stands as a formative principle. It is shown the possibility of extrapolation of methodical instructions developed for the concept of "unit of psyche's analysis" to the concept of "unit of sociopsychological analysis". At the same time, the term "personality" is substantiated, to sum up, the concept of "unit of analysis of socio-psychological". It is substantiated the formulation of the problem of demarcation of components of socio-psychological taxonomy as a question of the variability of socio-psychological forms of the psyche. As an empirical interpretation of the relationship between the problem of variability of socio-psychological forms of psyche with the problematic scope of its future development, an assumption is made about the specifics of sociopsychological conditionality of image characteristics.

Keywords: socio-psychological unit; socio-psychological taxonomy; collective subjectivity; forms of psyche.

Постановка проблеми. У межах наявного соціально-психологічного дискурсу досить експліцитними є уявлення щодо таксономії об’єктів вивчення (Андреева, 2007, с. 142). При цьому таксоном постає як більш-менш цілісна складова. Зокрема, цілком усталеними $є$ такі складові таксономії, як особистість, мала група, середня група (організація), велика група. Великі групи містять у собі таксони груп організованих і груп стихійних (там само, с. 148). Як бачимо, наявна соціально-психологічна таксономія базується на принципах будь-якої систематики - упорядкованості за критеріями системності, ієрархічності, супідрядності, співвідношення та обсягу.

Утім, зрозуміло, що соціально-психологічна систематика вибудовується в умовах низки відкритих проблем, таких як особистість/суспільство, колективна/індивідуальна суб'єктність, особистість/індивідуальність, які розмивають насамперед упорядкованість на рівнях співвідношення та обсягу таксонів. Вдавшись до образного порівняння, можемо говорити про “короткі замикання” суперечностей саме на перетинах об'єктів розмежування. Зокрема, Г. Андреєва у межах запропонованої таксономії розглядає проблематику класифікації місця суспільного руху в просторі таксонів стихійної/організованої груп (Андреева, 2007, с. 176). У доробку А. Брушлинського та його послідовників актуалізується проблематика розмежування індивідуального/колективного суб'єктів (Журавлев, 2009, с. 72). В. Васютинський як “одвічне” розглядає проблематичність водорозділу між Я/Ми (Васютинський, 2010, с. 32). Як не менш проблемне дослідник означує співвідношення між реальною групою та спільнотою, з одного боку, і спільнотою/масою - 3 другого (там само, с. 7-9). На проблематику демаркації стихійної контактної групи в межах таксонів груп середніх і великих звертає увагу М. Слюсаревський (2018, с. 127). У межах постмодерних настановлень та методології постнекласичного дискурсу соціальності пропонується переглянути категорію особистості, насамперед під кутом зору проблематики іiі розпорошеності на межах інтерсуб'єктивного простору комунікативних полів (Титаренко, 2014 , c. $25-26,32-33)$.

Аналіз останніх досліджень і публікацій, виокремлення нерозв'язаних частин загальної проблеми. Означені місця “коротких замикань” спонукають до рефлексії та виокремлення тих підстав побудови таксономії, які, вочевидь, є додатковими щодо загальних принципів побудови систематики і якими, як доцільно припустити, і зумовлено проблемну 
демаркацію соціально-психологічних таксонів. Інакше кажучи, йдеться про необхідність експлікації специфіки постання соціально-психологічного таксона як такого, а це й “зосереджує” проблему не в колі принципів побудови систематики, а в колі принципів виокремлення таксона.

Як підхід до виокремлення таксона, як це демонструє наведена на початках таксономія Г. Андрєевої, можна розглядати ідею кількісного розподілу. Тобто припускається, що наявність певної кількості елементів у межах тієї або тієї сукупності $\epsilon$ достатньою підставою для класифікації та первинної специфікації об'єкта аналізу. При цьому, як бачимо, більш-менш зберігається соціологічний підхід до виокремлення предмета аналізу, а отже, до певної міри, проблема демаркації складових соціально-психологічної таксономії в межах первинної специфікації може бути проілюстрована відомим евбулідівським парадоксом "Купа".

Як відомо, за допомогою цього парадоксу демонструється проблематика невизначеності, яка спонукає до розробки нечіткої логіки (Williamson, 1997). У іiї межах запропоновано ймовірнісний підхід до вирішення проблеми демаркації входження елемента в сукупність, яка має ознаки нечіткої множини. Тобто, по суті, пропонується обчислювати вірогідність того, наскільки виконується правило тотожності (множина залишається самототожною) під час здійснення в ії межах елементарних арифметичних операцій (n+1; n1) (там само, р. 924). При цьому перевіряється діапазон функції істинних значень при, як правило, числових уточненнях визначення сукупності. Утім, зрозуміло, що якщо більш строго підійти до розкриття змістового навантаження терміна “купа" - як до сукупності (як правило, однорідних елементів), обчислення кількісного складу якої неможливе, недоцільне або занадто трудомістке, тобто такої сукупності, щодо якої проблематичним $є$ застосування числа i, відповідно, операцій обчислення, - то парадокс знімається. Неважко помітити, що в межах соціально-психологічного дискурсу означене розуміння “купи” еквівалентне поняттю "маса" і, дещо меншою мірою, номінальному полюсу спільноти (Васютинський, 2010, с. 18).

Можемо підсумувати, що в межах проблеми демаркації соціально-психологічних таксонів соціологічний підхід до соціально-психологічної проблематики постулює принципову складеність таксонів 3 елементів, обчислення сумарної характеристики яких, утім, не завжди видається можливим. Отже, як можливість обчислення, так і результат обчислення кількісного складу сукупності можна вважати критерієм первинного упорядкування таксонів щодо співвідношення та обсягу.

Натомість традиційно усталений у добу класичної раціональності підхід до соціальнопсихологічної проблематики, де остання постає як сполучна ланка між соціологічним i психологічним аналізом, переводить предмет аналізу таксономії в річище інтрапсихічного розгляду, постулюючи можливість вести мову про соціально-психологічні таксони (групи) як складові індивіда (Слюсаревський, 2007, с. 53). Тоді завдання соціально-психологічного аналізу зводиться до синтезу цих, вочевидь, діаметрально протилежних підходів, маючи на меті розкрити способи буття таксона (колективного суб’єкта) в межах індивіда (там само). Звідси випливає, що вторинну специфікацію таксона поставлено в залежність від якісної специфіки тих елементів, що становлять сукупність. Доброю ілюстрацією такого підходу може слугувати уведена, зокрема, Л. Виготським диференціація понять елемент/одиниця як підгрунтя принципово відмінних видів аналізу (Выготский, 1982, с. 17-16). При цьому критерієм диференціації означених понять стає реалізація принципу “голографічності" в підході до визначення терміна “одиниця". Тобто припускається, що на відміну від елемента певної сукупності, який репрезентує лише себе як частину даної сукупності, одиниця як елемент сукупності (у повному або більш-менш згорнутому вигляді) містить у собі репрезентацію всієї сукупності.

Відповідно, якщо вести мову про людство як ідеальний об'єкт соціальної психології, де його ідеальність обумовлена покладанням усе-спільності, єдності як необхідного кінцевого результату еволюції людського виду (Слюсаревський, 2005, с. 12) i, тим самим, як гранично можливої сукупності (тобто сукупності всіх сукупностей), то розмаїття таксонів на 
такому ідеальному об'єкті може бути виокремлене і впорядковане принаймні у два способи: за критерієм можливості та/або результату обчислення елементів сукупності; за критерієм організованості сукупності за елементами чи одиницями. При цьому зрозуміло, що елемент та одиниця як способи організації соціально-психологічного таксона перебувають радше у відносинах несумісності, аніж взаємодоповнення. У межах психологічного дискурсу ця обставина, власне, й утілюється в розмежуванні термінологічних навантажень понять індивід/особистість (Ткаченко, 2009, с. 114-117). Так, самоочевидно, що якщо таксон задано за елементами, то таким елементом є індивід. Хоча варто зауважити, що в разі такого позиціонування не враховується змістове навантаження терміна “індивід”, де під ним розуміється результат переважно біологічної детермінованості людини (там само). Щоправда, якщо взяти до уваги думку тих дослідників, які визначають особистість як сукупність набутих у процесі соціалізації ролей і статусів (соціологічний підхід, наприклад, у Б. Парыгина $(1971$, с. 101)), то особистість постає як концепт, який відбиває результат "реалізації” на індивіді переважно соціальної детермінованості людини (там само, с. 61-62). Водночас, якщо розглядати термін “особистість" як “одиницю" аналізу соціальнопсихологічного таксона, то, крім ролей і статусів, у концепті особистості, окрім іншого, також відбиваються ті спільнотні характеристики, які “реалізовуються” в індивіді як члені певної сукупності, що, власне, і робить його одиницею цієї сукупності.

Отож бачимо, що розуміння особистості як сукупності соціально-психологічних одиниць, що актуально чи потенційно може бути “реалізованою” в індивіді, постає як критерій вторинного упорядкування таксонів, що, утім, жодним чином не полегшує проблему їх демаркації щодо співвідношення та обсягу. Тому маємо підстави припустити, що в розкритих підходах до розробки проблематики демаркації соціально-психологічних таксонів не враховуються настановлення такого підходу, де соціально-психологічний аналіз мислиться не як "бідна пасербиця" психологічного та соціологічного аналізу (Слюсаревський, 2013, с. 12), а від початків містить як свій предмет незвідну до суголосної феноменології специфіку.

Мета статті полягає в аналізі можливості постановки питання про варіативність соціально-психологічних таксонів та підгрунтя їх демаркації.

Виклад основного матеріалу дослідження. Якщо прийняти тезу про “непрозорість" психічного як постулат, то можна експлікувати низку наслідків. Перший самоочевидний наслідок доречно сформулювати у вигляді імплікації, а саме: якщо психіка "непрозора", то зв'язок носія психічного з іншим носієм психічного можливий лише опосередковано. Звідси, якщо опосередкованість зв'язку між носіями психічного (незалежно від того, що виступає його посередником) $є$ неодмінною умовою, то психіка, пов'язана 3 іншою психікою, i, навпаки, не пов'язана - це принципово різні форми існування психічного.

А втім, якщо зв'язок $є$ формою існування цілого, то пов'язаність - такою його характеристикою, у якій розкривається якісно специфічна відмінність існування елементів у формі цілого. Відтак, якщо припускати, що соціально-психологічний зв'язок (тобто зв'язок одного носія психічного з іншим носієм психічного) виконує функцію окремого виду зв'язку, то характеристика пов'язаності, притаманна цьому виду зв'язку, має бути уточнена в терміні “спільність”. При цьому доречно наголосити, що спільність як характеристика утвореного в просторі соціально-психологічної взаємодії зв'язку (тобто характеристика соціальнопсихологічного як явища загалом) увиразнює (характеризує) в собі: з одного боку - специфіку набуття та функціонування такого зв'язку, з другого боку - специфіку того “цілого”, що утворилося внаслідок зв'язку. Тобто спільність є змістовно залежною: від специфіки посередника зв'язку та зовнішньо- або внутрішньосуб'єктних процесів взаємодії з таким посередником; від специфіки утвореної внаслідок зв'язування (спілкування) структури “цілого”.

Звідси випливає, що порушена проблематика, а отже, і необхідність подальшої розробки конструкта “спільність”, лежить у площині того підходу до предметної специфіки соціально-психологічних явищ, який представлено в доробку Л. Виготського. Ідеться, зокрема, про широковідоме його твердження, що “колектив створює у тієї чи іншої дитини 
вищі психічні функції' (Выготский, 1983, с. 146), де, вочевидь, колектив і постає у формі певного цілого. Власне, уже неважко узагальнити цитоване твердження як окремий підхід до предметної проблематики соціальної психології, мета якого - розкрити специфіку соціальнопсихологічної зумовленості психічного.

Усталена в сучасному соціально-психологічному дискурсі специфіка соціальнопсихологічної зумовленості може бути розкрита 3 огляду на уявлення про предмет соиіальної психології. Звернімося до визначення, запропонованого М. Слюсаревським, який об’єднує в ньому “індивідуальні та надіндивідуальні (групові, колективні, масові) психічні явища, що зумовлюються історичною та культурною єдністю людей, їх взаємодією, спільною діяльністю і виявляються в особливостях індивідуальної, групової та міжгрупової поведінки" (Слюсаревський, 2013, с. 30). Як бачимо, ідеться про певні феномени (психічні явища), які вирізняються 3-поміж інших психічних явищ за конкретним критерієм їхньої зумовленості. Отже, соціально-психологічна феноменологія, яка відображається в певних психологічних (чи психічних) характеристиках, що виявляють себе в поведінкових феноменах різного рівня даності, за визначенням зумовлюється цілком конкретним рядом чинників. Отже, наведений ряд зумовлення - історична і культурна єдність людей, їхня взаємодія, спільна діяльність - у першому наближенні й постають як специфічно соціальнопсихологічні чинники. При цьому в межах першого елемента ряду чинником $\epsilon$ історичний та соціокультурний процес розвитку людства, тоді як третій елемент ряду постає як конкретизований момент взаємодії, тобто конкретизує другий елемент ряду.

Отож у підсумку бачимо, що специфіка соціально-психологічного спричинення розкривається як зумовленість психічних феноменів процесом взаємодії людей, яка розгортається на тлі здобутків безперервного історично-культурного процесу розвитку людства та проявляється в еволюціонуванні поведінкових феноменів людини. Проілюструвати означене можна, вдавшись до рефлексії конкретних наслідків такого позиціонування специфіки соціально-психологічної зумовленості. Зокрема, у диспозиційній моделі зумовлення соціальної поведінки В. Ядова представлено ієрархічну чотириступеневу сукупність трьох рядів взаємозалежних змінних - потреб, ситуацій їх задоволення та диспозицій (Ядов, 2013). Диспозиції при цьому дослідник розглядає як закріплені в досвіді характеристики особистості, набуті внаслідок “зіткнення" потреб і типових ситуацій їх задоволення (які, очевидно, змінюються в процесі культурно-соціального поступу). Утворившись за певних умов, диспозиційні утворення в подальшому виконують регулятивну функцію щодо соціальної поведінки людини.

Можемо відтак виснувати, що диспозиція є типовим утворенням, яке має соціальнопсихологічну природу, адже поєднує в собі наявні характеристики особистості. Тому специфіка соціально-психологічної зумовленості розкривається радше як специфіка соціальнопсихологічного, аніж психічного, спричинення поведінки. При цьому самі чинники, що зумовлюють специфіку соціально-психологічного як явища, винесено “за межі” людини - у простір історично-культурного ряду явищ. Натомість позиціонування соціальнопсихологічного зв'язку як принципово відмінної форми існування психічного припускає й необхідність розкриття специфіки соціально-психологічної зумовленості психічного як такого. Тобто розкриття зворотного впливу набутої в процесі спілкування спільності як характеристики зв'язку і, відповідно, форми цілого на функціонування психічного в цій новій формі. Адже, якщо повернутися до зауваженого на початках аналізу засновку про “непрозорість" психічного, стає очевидним, що новоутворене “ціле” як форма психічного принципово не може бути винесене за межі носія психічного без втрати сутнісної характеристики - психічного. При цьому новоутворене “ціле” з позиції концепту соціальнопсихологічної одиниці актуалізує порушену проблематику в межах більш загального проблемного обширу “ідеї цілого”, адже одиниця як певна усталена форма за необхідністю стає носієм характеристики цілісності. "Ідея цілого" як загалом, так і в межах соціальнопсихологічної проблематики може мати досить просте формулювання: ціле не зводиться до 
сукупності своїх частин (Слюсаревський, \& Хазратова, 2013). Це формулювання також надає осмисленості висловлюванню “динаміка функціонування частин зумовлена цілим” (там само).

Отже, соціально-психологічна інтерпретація ідеї цілого спричинює своєрідне розуміння цілісності як формотворчого принципу організованості соціально-психологічного таксона. Інакше кажучи, цілісність як емерджентна властивість зумовлює виникнення певної сукупності, упорядкованої цілісністю. Виходить, соціально-психологічна інтерпретація ідеї цілого відтворює усталену проблему цілісності, де пояснення потребує як емерджентний перехід кількості в нову якість, так і, власне, специфіка зворотного впливу емерджентних новоутворень на ту множину елементів, на якій реалізується цілісність. Водночас така інтерпретація в контексті проблематики демаркації складових соціально-психологічної таксономії не лише зумовлює відтворення усталеної проблеми цілісності, а й спричинює суто предметно-специфічне питання щодо специфіки постання об'єктів соціальнопсихологічної таксономії, де цілісність є формотворчим принципом.

3 дискурсу історії соціально-психологічного знання можемо зауважити, що уявлення про специфіку зумовлення елементів цілим зазнали своєрідного розвитку. Зокрема, завдяки реконструкції С. Московічі соціологічного вчення Е. Дюркгайма виявлено позиціонування такого впливу через розрізнення механічної та органічної солідарності як способу зв'язку між людьми. Зокрема, підгрунтям першого типу солідарності $є$ колективна свідомість, підгрунтям другого - розподіл праці (Московичи, 1998). Таким чином, розробка уявлень про підгрунтя взаємозв'язку між людьми стала підставою для гіпотези про існування суспільства, яке, відповідно, являє собою зовнішню детермінанту зв'язку людини з людиною, вплив якої за необхідністю пов'язаний з функцією примусу цього гіпотетичного суб'єкта. Окрім того, самим С. Московічі переосмислено специфіку такого впливу, й із зовнішньої щодо людини детермінанту примусу перетворено на внутрішню та виражено в змістових навантаженнях таких термінів, як “колективні вірування та уявлення", “ідея”, “харизма” тощо (там само). Тобто можемо зауважити, що специфіка зумовленості взаємозв’язку між цілим і його частинами розкрита через позиціонування детермінанти примусу до зв'язку (утримання форми цілого) як внутрішнього чинника.

Позиціонуючи новоутворене "ціле" як внутрішній щодо людини чинник, бачимо, що методологічне підгрунтя його аналізу зосереджене в межах вищезгаданих настанов Л. Виготського щодо критеріїв виокремлення концепту “одиниця аналізу психічного”. Так, видається цілком припустимим екстраполювати ці настанови на концепт "одиниця аналізу соціально-психологічного” (як форми психічного). При цьому так само можна припустити, що термін "особистість” якраз і є “одиницею аналізу соціально-психологічного”, яка за необхідністю репрезентує собою певне ціле, частиною якого вона є. Щоб проілюструвати означене, доречно звернутися до процесуального підходу до розробки цього поняття, що реалізований, зокрема, у моделі Т. Титаренко. Згідно з цією моделлю особистість - це суб'єкт самоконструювання, який проявляє себе не так у поведінці (індивідуальній, груповій чи міжгруповій), як у процесах ідентифікування, діалогування, автономізації та практикування (Титаренко, 2014). Тобто в процесах безпосередньої репрезентації себе як актуалізованої (даної “тут і тепер») одиниці певного цілого, з яким вона перебуває не лише у відношеннях репрезентації, а й повсякчасної взаємодії, результати якої, власне, безперервно й репрезентуються.

Отже, складові таксономії мають залежати від специфіки набуття та функціонування спільності, тобто від результатів процесу спілкування (як процесу утворення зв'язку) (Коваль, 2018). Виходить, процес утворення зв'язку має бути дотичним також і до утворення певного "цілого", з яким особистість перебуває у відносинах репрезентації. Оскільки природа “форми цілого” виявляється як внутрішній щодо людини результат зв”язку, то питання щодо складових таксономії може бути сформульовано як питання щодо наявної варіативності соціально-психологічних форм психічного і меж між ними, інакше кажучи щодо кількісної характеристики форм спільності та підгрунтя демаркації між означеними формами. Як бачимо, питання полягає в тому, що соціально-психологічна таксономія має 
розглядатися не під соціологічним кутом зору, де достатнім підгрунтям для демаркації між складовими таксономії $є$ уявлення про кількісний склад елементів цілого, що підлягають “зв'язуванню”, а під кутом зору уявлень про специфіку спільності як характеристики зв'язку між носіями психічного, який можливий лише за умови опосередкованості та обмежений носієм психічного.

Формулювання твердження про специфіку соціально-психологічної зумовленості психічного припускає, що в цьому твердженні взаємовідношення між соціальнопсихологічним і психічним розкривається як взаємовідношення між формою і змістом, де соціально-психологічне як форма психічного є чинником щодо змістів психічного. При цьому останні розкриваються як традиційно усталене в психологічному дискурсі узагальнення основного продукту психічного - суб'єктивного образу об'єктивної дійсності. Це значить, що специфіка соціально-психологічної зумовленості, очевидно, має полягати в тому, що в межах соціально-психологічних форм психічного створюються можливості для продукування принципово відмінних від інших форм психічного змістів психічного.

Отже, особистість як одиниця аналізу складових соціально-психологічної таксономії змістовно постає як суб'єкт зумовлення специфіки колективної суб'єктності (як динамічного аспекту спільності). Тобто специфіка колективної суб'єктності (як чинника активності) у соціально-психологічному своєму зумовленні залежить від реалізації інтегративної функції особистості, аргументом якої $є$ певний вид спільності. Конкретно - від процесів, що реалізуються особистістю щодо певного цілого (складника соціально-психологічної таксономії), неподільною частиною якого особистість $є$ і відносини 3 яким вона собою репрезентує. Тому інтегративна функція особистості може бути розкрита як функція відповідності певному соціально-психологічному таксону, тобто особистість як одиниця аналізу може набувати певного значення щодо обмеженої множини потенційно можливих значень. Отож залежно від набутого значення має спостерігатися варіативність зумовлення характеристик суб'єктивного образу об'єктивної реальності.

Усі ці зауваги не лише створюють методологічні передумови для теоретичного обгрунтування можливості постановки питання про варіативність соціально-психологічних форм психічного, а й означують також напрям просування в питанні можливості емпіричної перевірки теоретично обгрунтованих припущень. Тобто якщо буде показано відтворення на образі зумовлених специфікою набутої спільності характеристик, то тим самим також буде продемонстровано неоднорідність тих “цілих", щодо яких інтегративна функція особистості виконується. Отже, вирішення проблеми демаркації складових соціально-психологічної таксономії ми “підводимо” під проблематику характеристик суб'єктивного образу об'єктивної дійсності, де специфікою певного "цілого" має бути задано варіативність критеріїв конституювання образу.

Висновки та перспективи подальших досліджень. Показано, що проблему демаркації складових соціально-психологічної таксономії можна сформулювати як питання про варіативність соціально-психологічних форм психічного. При цьому припущення про специфіку соціально-психологічної зумовленості характеристик конституйованого образу постає як емпірична інтерпретація взаємозв'язку проблеми варіативності соціально-психологічних форм психічного з проблемними обширами іiі перспективної розробки. У межах емпіричної апробації концептуальних засад дослідження порушеної проблематики першочергове завдання полягає в методичному забезпеченні виявлення специфіки реконструкції на образі характеристик “цілого” в їх зумовленості соціально-психологічним таксоном.

Разом 3 тим сформульовано й низку зауваг, що показують проблематичність такого спрощеного підходу до формулювання концептуальних засад дослідження варіативності соціально-психологічних форм психічного та можливостей їх емпіричної апробації. Якщо позиціонування форм соціально-психологічного зв'язку як специфічних форм психічного $\epsilon$ підгрунтям специфікації характеристик суб'єктивного образу об'єктивної дійсності, то має йтися про таке новоутворення, як простір постання та функціонування специфічно своєрідних змістів психічного. А проте якщо дотримуватися постулату "непрозорості" 
психічного, то зв'язок носіїв психічного можливий лише за умови опосередкованості і він має бути обмежений носієм психічного. Тобто посередник, завдяки якому уможливлюється зв'язок, сам має бути даним як зміст психічного. Звідси випливає, що в людині “реалізовується” не лише соціально-психологічний зв'язок, а й інші форми психічного, щодо яких людина $є$ носієм множинної суб'єктності. Тобто йдеться про необхідність виокремлення варіативності суб'єктних активностей, що “реалізуються” в людині у тій чи тій формі організації психічного. При цьому зовсім не очевидною є відповідь на питання щодо синхронічності, або, навпаки, послідовності такої реалізації. Це означає, що на образі буде відображена не лише специфіка соціально-психологічного таксона, а й специфіка інших форм психічного. Тому проблема полягає в можливості диференціації характеристик, заданих різними формами психічного у змісті психічного. Цьому, утім, мають передувати аналіз та диференціація варіативності форм психічного, що “реалізуються" в людині і в сукупності породжують простір постання та функціонування специфічних об'єктів-образів як основного змісту (продукту) психічного.

Подальший теоретичний аналіз наведених зауваг до формулювання концептуальних засад дослідження варіативності соціально-психологічних форм психічного є перспективним напрямком розробки порушеної проблематики.

\section{Список використаних джерел}

Андреева, Г. (2007). Социальная психология. (5-е изд.). Москва: Аспект Пресс.

Васютинський, В. (2010). Психологічні виміри спільноти. Київ: Золоті ворота.

Выготский, Л. (1983). История развития высших психических функиий. Собрание сочинений: в 6-ти томах. Т.3. Москва: Педагогика.

Выготский, Л. (1982). Мышление и речь. Собрание сочинений: в 6-ти томах. Т.2. Москва: Педагогика.

Журавлев, А. (2009). Коллективный субъект: основные признаки, уровни и психологические типы. Психологический журнал, 30(5), 72-80.

Коваль, Г. (2018). Модель спілкування в дослідженні і виокремленні специфіки колективної суб'єктності. Проблеми сучасної психології, 2(14), 50-60.

Московичи, С. (1998). Машина, творящая богов. Москва: Центр психологии и психотерапии.

Парыгин, Б. (1971). Основы соииально-психологической теории. Москва: Мысль.

Слюсаревський, М. (2013). Історіогенез соціальної психології як джерело уявлень про іiі змістовий обсяг і дисциплінарну будову. В М. М. Слюсаревський (Ред.), Iсторіографічні та методологічні координати теорій сочіальної психології (с. 9-33). Кіровоград: Імекс-ЛТД.

Слюсаревський, М. (2005). Методологічна ситуація в психологічній науці та перспективи соціальної психології. Наукові студї̈ із соціальної та політичної психології, 10(13), 3-14.

Слюсаревський, М. (2007). Належність до спільноти як соціально-психологічний феномен. Психологічні перспективи, 10, 53-58.

Слюсаревський, М. (2018). Наукові уявлення про складові психіки великих груп: спроба “інвентаризації”. Наукові студї із соціальної та політичної психології, 41(44), 126-156.

Слюсаревський, М., \& Хазратова, Н. (2013). Основні зарубіжні та радянські соціальнопсихологічні теорії. В М. М. Слюсаревський (Ред.), Історіографічні та методологічні координати теорій соицальної психології (с. 155-212). Кіровоград: Імекс-ЛТД.

Титаренко, Т. (2014). Соціально-психологічні практики особистісного життєконструювання. В Т. Титаренко, О. Кочубейник, К. Черемних, Психологічні практики конструювання життя в умовах постмодерної соціальності. Київ: Міленіум.

Ткаченко, О. (2009). Принципи, категорії і методологічні проблеми психології. Психологія $i$ суспільство, 1(35), 44-133.

Ядов, О. (2013). Саморегулящия и прогнозирование сочиального поведения личности: Диспозищионная конщепщия. Москва: ЦСПиМ.

Williamson, T. (1997). Vagueness. Philosophy and Phenomenological Research, 57(4), 921-928. Retrieved from https://www.jstor.org/stable/2953810. 


\section{References} Russian)

Andryeva, G. (2007). Sotsialnaya psikhologiya [Social Psychology]. Moscow: Aspekt Press. (in

Koval, H. (2018). Model spilkuvannia v doslidzhenni i vyokremlenni spetsyfiky kolektyvnoi subiektnosti [The model of communication in a research and differentiation of a specificity of collective subjectivity]. Problems of modern psychology, 2(14), 50-60. (in Ukrainian)

Moskovichi, S. (1998). Mashina, tvoryashchaya bogov [A machine that creates gods]. Moscow: Tsentr psikhologii i psikhoterapii. (in Russian)

Parygin, B. (1971). Osnovy sotsialno-psikhologicheskoy teorii [Basis of socio-psychological theory]. Moscow: Mysl. (in Russian)

Slyusarevskyy, M. (2013). Istoriohenez sotsialnoi psykholohii yak dzherelo uiavlen pro yii zmistovyi obsiah i dystsyplinarnu budovu [The historiogenesis of social psychology as a source of ideas about its semantic scope and disciplinary structure]. In M. M. Slyusarevskyy (Ed.), Historiographical and methodological coordinates of theories of social psychology (pp. 9-33). Kirovohrad: Imeks-LTD Publ. (in Ukrainian)

Slyusarevskyy, M. (2005). Metodolohichna sytuatsiia v psykholohichnii nautsi ta perspektyvy sotsialnoi psykholohii [Methodological Situation in Psychological Science and Social Psychology Prospects]. Scientific studios on social and political psychology, 10(13), 3-14. (in Ukrainian)

Slyusarevskyy, M. (2007). Nalezhnist do spilnoty yak sotsialno-psykholohichnyy fenomen [Belonging to the community as a socio-psychological phenomenon]. Psykholohichni perspektyvy, 10, 5358. (in Ukrainian)

Slyusarevskyy, M. (2018). Naukovi uiavlennia pro skladovi psykhiky velykykh hrup: sproba "inventaryzatsii" [Scientific Ideas on Psychics Components of Large Groups: Inventorization Attempt]. Scientific studios on social and political psychology, 41(44), 126-156. (in Ukrainian)

Slyusarevskyy, M., \& Khazratova, N. (2013). Osnovni zarubizhni ta radianski sotsialnopsykholohichni teorii [Basic foreign and Soviet socio-psychological theories]. In M. M. Slyusarevskyy (Ed.), Historiographical and methodological coordinates of theories of social psychology (pp. 155-212). Kirovohrad: Imeks-LTD Publ. (in Ukrainian)

Tkachenko, O. (2009). Pryntsypy, katehorii i metodolohichni problemy psykholohii [Principles, categories and methodological problems of psychology]. Psychology and Society, 1(35), 44-133. (in Ukrainian)

Tytarenko, T. (2014). Sotsialno-psykholohichni praktyky osobystisnoho zhyttiekonstruiuvannia [Socio-psychological practices of personal life design.]. In T. Tytarenko, O. Kochubeinyk, K. Cheremnykh, Psykholohichni praktyky konstruiuvannia zhyttia v umovakh postmodernoi sotsialnosti. Kyiv: Millennium. (in Ukrainian)

Vasiutynskyi, V. (2010). Psykholohichni vymiry spilnoty [The psychological dimensions of the community]. Kyiv: Zoloti vorota. (in Ukrainian).

Vygotskiy, L. (1982). Istoriya razvitiya vysshykh psikhicheskikh funktsiy Sobraniye sochineniy: v 6 tomakh. Tom 3. [The history of the development of higher mental functions]. Moscow: Pedagogy. (in Russian)

Vygotskiy, L. (1982). Myshleniye i rech. Sobraniye sochineniy: v 6 tomakh. Tom 2. [Thinking and Speaking]. Moscow: Pedagogy. (in Russian)

Williamson, T. (1997). Vagueness. Philosophy and Phenomenological Research, 57(4), 921-928. Retrieved from https://www.jstor.org/stable/2953810. (in English).

Yadov, O. (2013). Samoregulyatsiya $i$ prognozirovaniye sotsialnogo povedeniya lichnosti: Dispozitsionnaya kontseptsiya [Self-regulation and forecasting of social behavior of a person: Dispositional concept]. Moscow: TSSPiM. (in Russian)

Zhuravlev, A. (2009). Kollektivnyy subyekt: osnovnyye priznaki, urovni i psikhologicheskiye tipy [Collective subject: main attributes, levels and psychological types]. Psychological journal, 30(5), 72-80. (in Russian) 